\title{
Medium- and Short-Term Interventions with Ma-Pi 2 Macrobiotic Diet in Type 2 Diabetic Adults of Bauta, Havana
}

\author{
Carmen Porrata-Maury, ${ }^{1}$ Manuel Hernández-Triana, ${ }^{2}$ Eduardo Rodríguez-Sotero, ${ }^{3}$ \\ Raúl Vilá-Dacosta-Calheiros, ${ }^{1}$ Héctor Hernández-Hernández, ${ }^{4}$ Mayelín Mirabal-Sosa, ${ }^{1}$ \\ Concepción Campa-Huergo, ${ }^{5}$ and Mario Pianesi ${ }^{6}$
}

\author{
${ }^{1}$ Clinical Assay Direction, Finlay Institute, Avenue 27, No. 19805, La Coronela, La Lisa, Havana 11600, Cuba \\ ${ }^{2}$ Latin American Nutrition Society, Iberoamerican Nutrition Foundation, and Department of Biochemistry and Physiology, \\ Institute of Nutrition, Infanta 1158, Havana 10300, Cuba \\ ${ }^{3}$ Direction, Diabetic Care Center, Carretera Central km 29.5, Bauta 32400, Artemisa, Cuba \\ ${ }^{4}$ Lipid Metabolism Laboratory, Department of Biochemistry and Physiology, Institute of Nutrition, Infanta 1158, \\ Havana 10300, Cuba \\ ${ }^{5}$ Presidency, Finlay Institute, Avenue 27, No. 19805, La Coronela, La Lisa, Havana 11600, Cuba \\ ${ }^{6}$ Presidency, UPM Un Punto Macrobiotico, Viale San Nicola, 62029 Tolentino, Italy
}

Correspondence should be addressed to Carmen Porrata-Maury, cporrata@infomed.sld.cu

Received 30 May 2012; Revised 1 September 2012; Accepted 2 September 2012

Academic Editor: H. Boeing

Copyright (C 2012 Carmen Porrata-Maury et al. This is an open access article distributed under the Creative Commons Attribution License, which permits unrestricted use, distribution, and reproduction in any medium, provided the original work is properly cited.

\begin{abstract}
Background. In Cuba, the Ma-Pi 2 macrobiotic diet has shown positive results in 6-month assays with type 2 diabetic patients. The objective of this study was to assess the influence of this diet at short and medium terms. Methods. Sixty-five type 2 diabetic volunteers were included for dietary intervention, institutionally based for 21 days and followed later at home, until completing 3 months. 54 of them stayed until assay end. Before intervention, and after both assay periods, they were submitted to anthropometric records, body composition analyses and measurements of serum biochemical indicators, glycemic profile in capillary blood, blood pressure, and medication consumption; food intake was evaluated by the 3-day dietary recall. Results. During the intervention, the energy intake was $200 \mathrm{kcal}$ higher at instance of more complex carbohydrates and dietary fiber and despite less fat and protein. Blood pressure and serum biochemical indicators decreased significantly in both periods; the safety nutritional indicators (hemoglobin, serum total proteins, and albumin) showed no variations. The global cardiovascular risk decreased and insulin consumption dropped by $46 \%$ and $64 \%$, in both periods, respectively. Conclusions. The Ma-Pi 2 macrobiotic diet was a successful therapy at short term and after 3-month home-based intervention, for type 2 diabetics.
\end{abstract}

\section{Introduction}

Between 2010 and 2030, there will be a 69\% increase of adults with diabetes in the developing countries [1]. The Italian International Association Un Punto Macrobiotico, UPM, founded and presided by Mario Pianesi, in collaboration with the Finlay Institute in Havana have shown positive results after 6 months of dietary institutional interventions with macrobiotic Ma-Pi 2 diet in adults affected with type 2 diabetes mellitus [2, 3]. The objective of this study was to prove those dietary effects at short term (after 21 days of controlled institutional administration) and also at medium term following 3 months during which patients remained incorporated to their daily life and were responsible for their own feeding.

\section{Materials and Methods}

The study was carried out at the Diabetic Care Center (DCC) of the municipality of Bauta, Havana, it was not a randomized double-blind trial. Instead of including a control 
group, which may be a limitation, a prospective cohort study was designed in 65 adult volunteers been evaluated at onset, 21 days and at 3 months at the end of the intervention.

2.1. Sample Size. According to previous results [2, 3], for a power of $85 \%$ and a significance level of $\alpha=0.05$, a sample size of 40 individuals should be enough for detecting reductions of $26 \%$ in glycemia, $8 \%$ in total cholesterol, $12 \%$ in LDL cholesterol, and 18\% in triglycerides.

2.2. Ethical Considerations. The study followed the recommendations of the 2000 Declaration of Helsinki [4], all participants were informed about the study procedures, patients' information was recorded in data collection charts, and the study protocol was approved by the Scientific Councils and Ethics Committees of the Finlay Institute and the Nutrition and Food Hygiene Institute (INHA, its Spanish acronym).

2.3. Inclusion Criteria. Confirmed diagnosis of type 2 diabetes [5]; age between 20 and 80 years; pharmacological treatment with insulin, hypoglycemic drugs, or both; dietotherapy regimen established by the Cuban Institute of Endocrinology received; periodical DCC medical controls fulfilled and written consent of participation provided.

2.4. Exclusion Criteria. Presence of concomitant factors able to modify the carbohydrates or lipid metabolism parameters (illnesses, drugs consumption), mental inability, addictions, hemoglobin $<10 \mathrm{mg} / \mathrm{dL}$, and $\mathrm{BMI}<18.5$.

2.5. Exit Criteria. Dietary intolerance or non-acceptance of the diet, unfulfillment of the dietary medical protocol, occurence of serious events, and voluntary abandonment of the study.

2.6. Adverse Events. Any medical manifestation during the intervention, related or not to the diet. Anemia, low body weight, and signs or symptoms of nutritional deficiencies or excesses, were considered as events related to diet.

2.7. Intervention Diet. Macrobiotic vegetarian Ma-Pi 2 diet $[6,7]$, designed for diseases considered with acid metabolic course. Total volume of the Ma-Pi 2 diet consisted of $40-50 \%$ whole grains (rice, millet, and barley), 40-50\% vegetables (carrots, kale, cabbage, broccoli, chicory, onions, red and white radish, and parsley), and $8-10 \%$ legumes (adzuki beans, chickpeas, lentils, and black beans); all foods derived from organic cultivations with no chemical additives. Gomasio (roasted ground sesame seeds with unrefined sea salt), fermented products (miso, tamari, and umeboshi), and seaweeds (kombu, wakame, and nori) were used as complements of the diet's nutritional value. Bancha tea (theine-free green tea) was the main source of liquid.

2.8. Study Development. During the first 21 days, patients should assist to the DCC, where they received daily full food service daily (breakfast, lunch, dinner, and snacks), prepared by expert Ma-Pi macrobiotic cooks as well as instruction in diet preparation methods, with the purpose of guarantying their self-sufficiency at home during the next days till completing 3 months of intervention. The patients underwent medical control, daily during the first 21 days and later on every week during the first month, and every 15 days during the two following months. Information on symptoms, signs, body weight, serum glucose profile, diet compliance, and adverse events was recorded; medication doses were adjusted.

Food consumption was evaluated by the 3-day dietary recall method ( 2 week days, 1 weekend day), in the three phases of the study (before the Ma-Pi diet, during the first 21 days $\mathrm{Ma}-\mathrm{Pi}$ diet, and during the 3 following months). Nutrient intake was calculated with international food composition charts [8-11] and compared with dietary reference intake values (DRIs) and tolerable upper intake limits [12-14] for vitamins and minerals. Amino acid score of the protein mix was assessed using the adult amino acids requirement values proposed by Millward [15], corrected by the $80 \%$ digestibility in the Ma Pi macrobiotic diet.

During the 3-month period, patients were supplied with whole rice, sesame as well as some small quantities of macrobiotic products as Bancha tea, seaweeds (wakame, kombu, and nori), and fermented products (miso, tamari, and umeboshi).

At onset, 21 days, and termination ( 3 months), patients were submitted to the following.

2.9. Anthropometric Measurements. body weight, body height, and waist and hip circumferences [16]. Body composition was also measured by bioelectrical impedance (Bioelectrical Impedance Analysis, BIO, Nutriguard-S, Serial No 103.06678, Darmstadt, Germany). Primary data were used for the calculation of the Body Mass Index (BMI = weight in $\mathrm{kg} /$ height in $\mathrm{m}^{2}$ ), body fat, and lean body mass.

2.10. Blood Biochemical Tests. They were carried out after 12-hour fast: glucose, total cholesterol, HDL cholesterol, LDL cholesterol, triglycerides, creatinine, urea, and hepatic alanine aminotransferase (ALAT). Hemoglobin, total protein, and albumin were tested as indicators of safety. All the determinations were carried out at the INHA, following international-approved protocols. Serum glucose and lipids were determined using an Automatic Analyzer ELIMAT (SEPPIM, France), commercial reagents kits from HELFADiagnostics, Cuba [17], and control serums Elitrol 1-2 for quality assessment of the results. The obtained variation coefficients were $2.0 \%$ for glucose, $1.1 \%$ for total cholesterol, $2.3 \%$ for LDL cholesterol, and $2.1 \%$ for triglycerides. Hemoglobin was measured in a Coulter Electronic Cell MH, Firm ABX Micro 60, France. The rest of the biochemical measurements were carried out using an Automatic Analyzer Hitachi 902 (Roche diagnostic GmbH, Hitachi HighTechnologies Corp., Japan), with commercial reagents kits from HELFA-Diagnostics, Cuba. Serum lipids were used for the estimation of the cardiovascular risk [18]. The glycemic 
profile in capillary blood was measured with glucometer (Roche, USA), during two whole days (three times a day: in fast, 2 hours after breakfast and two hours after lunch). Blood pressure was recorded with similar periodicity using a mercury sphygmomanometer (China).

2.11. Statistical Analysis. The statistical analysis of the data was carried out using the system R, version 2.7.0 for Windows. Results were expressed in means, standard deviations, minimum and maximum values. The ANOVA test and a significance level of $P \leq 0.05$ were used for comparisons. Graphics for data visualization were conformed using Statistica, version 7.0.

\section{Results}

Four subjects abandoned the assay during the first 2 days because of non-acceptance of the diet. The 61 remaining patients completed the assay protocol until day 21 . After this first phase, other 3 patients were excluded by apparent no fulfillment of the diet or the medical control, and other 4 requested their exclusion by different causes. Consequently, $54(88 \%)$ of the selected patients concluded the 3-month study. The mean age of the 61 participants was $59.98 \pm$ 10.55 years (age range 34-77y); mean body height was $166 \pm 8 \mathrm{~cm}(146-184 \mathrm{~cm})$. The sample was composed by 33 women (54\%) and 28 men (46\%). Daily diabetic medication consumption was high at onset: 53 patients used a total of 1341 insulin units (mean consumption: $25 \mathrm{u} /$ person and $0.3 \mathrm{u} / \mathrm{kg} \mathrm{Wt}$ ); 60 patients consumed 200 hypoglycemic pills (mean consumption 4 tabs/person).

3.1. Nutritional Characterization of the Food Intake. A mean $200 \mathrm{kcal}$ lower energy intake was recorded before intervention (20\% as proteins, $30 \%$ fats, and $50 \%$ carbohydrates), distribution which met nutritional recommendations for diabetes mellitus, but composed of higher animal products (including dairy products) and fruits, scarce vegetables, and no whole cereals. The mean dietary fiber consumption was only $18 \mathrm{~g} /$ day.

High whole grain cereals, vegetables, and legumes intake prevailed during intervention. At home, patients incorporated small quantities of other foods, not included in the MaPi 2 diet, as yam, pumpkin, lettuce, beet, cucumber, guava, water melon, chicken meat without skin, fish, and oil. However, these small transgressions, characteristic of open studies, scarcely modified the nutritional content of the diet. The transgressions were at the minimal level while the patients were receiving their food at the DCC macrobiotic dining hall and increased at home. The individual contributions of macronutrients to the total energy intake were protein $12 \%$, fat $16 \%$, and carbohydrate $72 \%$, or $12 \%, 18 \%$, and $70 \%$, in the $21 \mathrm{~d}$ or 3 -month intervention periods, respectively, which characterizes both as low-energy-density diets.

Mean daily energy intake increased around $200 \mathrm{kcal}$ in both intervention periods. The total daily nutrients intake with the Ma-Pi diet was above two-thirds of the daily DRIs, except for vitamin $B_{12}$, which only covered $22 \%$ of its DRI during the first intervention period and $60 \%$ in the second one, due to the addition of some animal food products. High intake levels of dietary fiber, vitamin C, folic acid, vitamin A (mainly carotenes), thiamine, pyridoxine, niacin, $\mathrm{Mg}, \mathrm{Mn}, \mathrm{Zn}$, and adequate values of Ca intake were recorded, in spite of the absence of dairy products (Table 1). The $80 \%$ digestibility-corrected amino acid score of the ingested protein was 99 (with methionine and cystine as limiting amino acids) during the first intervention period; during the second one, this value increased to 102 .

\subsection{Effect on Anthropometric Variables. Most anthropomet-} ric records showed an apparent decrease during the 3 months, but without statistical significance (Wt, $3.7 \mathrm{~kg}$; BMI, $4.9 \%$, and waist and hip circumferences 4.2 and $3.7 \mathrm{~cm}$, resp.). However, only the body fat reduction (3.1\%) was close to be statistically significant $(P=0.059)$, while the lean body mass remained unchanged (Table 2). The highest observed individual value of body weight loss was $12 \mathrm{~kg}$.

3.3. Effect of the Diet on Biochemical Indicators. Serum glucose, lipids, and other indicators reflected a non-optimal metabolic control at onset. The high glycemia value at onset $(8.35 \mathrm{mmol} / \mathrm{L})$ dropped fast during the first 3 days of intervention, parallel to the insulin consumption reduction. After 21 days, the $2 \mathrm{mmol} / \mathrm{L}$ reduction (23\%) was highly significant; 3 months later it was more evident $(2.7 \mathrm{mmol} / \mathrm{L}$, $32 \%)$, reaching values inside the metabolic control interval (Table 3, Figure 1).

The evolution of the glycemic profile evidenced also the adequate impact of the supplied diet on the control of carbohydrate metabolism (Table 4). The glycemia decreasing tendency in different moments of the day is showed in Figure 2. The data dispersion decreased during the treatment.

Serum lipids also decreased significantly after 21 days and 3 months. The HDL cholesterol values did not change significantly during the whole intervention (Table 3, Figure 3).

At onset, the patients showed a high cardiovascular risk, in agreement with the observed serum lipid figures. The MaPi 2 macrobiotic diet administration was associated to the significant cardiovascular risk decrease (Tables 3 and 5).

From all patients included in this study, $44(72 \%)$ had basal risk serum cholesterol levels $(>5.19 \mathrm{mmol} / \mathrm{L})$, including 31 subjects $(51 \%)$ with highly risky levels $(\geq 6.2 \mathrm{mmol} / \mathrm{L})$. After 21 days with the diet, the numbers decreased to 8 and only one patient, respectively. This good evolution was maintained 3 months later.

LDL cholesterol and triglycerides levels showed a similar behavior, while HDL cholesterol concentrations only evidenced a discrete and nonsignificant improvement (Table 5), which could indicate that more time is needed for an evident impact of the assayed diet.

The lipid ratios of total cholesterol/HDL cholesterol, LDL cholesterol/HDL cholesterol, and non-HDL cholesterol/HDL cholesterol decreased after 21 days 30\%, 34\%, and $36 \%$, respectively, and 3 months later they remained below the initial figures in $26 \%, 29 \%$, and $32 \%$, respectively (Table 6). The mean non-HDL cholesterol values were 5.11, 
TABLE 1: Average daily energy and nutrients intake during the assay periods versus Dietary Reference Intake (DRI) values and tolerable upper intake limits (ULI).

\begin{tabular}{|c|c|c|c|c|}
\hline \multirow{2}{*}{ Nutrient } & \multicolumn{3}{|c|}{ Average daily intake per person } & \multirow{2}{*}{ DRI-ULI } \\
\hline & Diet at home before & Ma-Pi diet at the DCC & Ma-Pi diet at home & \\
\hline Energy (kcal) & 1936 & 2174 & 2144 & 2000 \\
\hline Protein $(\mathrm{g})$ & 98 & 66 & 64 & 75 \\
\hline Tryptophan* & 13 & 13 & 13 & 7 \\
\hline Threonine* & 42 & 35 & 38 & 29 \\
\hline Isoleucine* & 50 & 41 & 43 & 34 \\
\hline Leucine* & 80 & 73 & 75 & 50 \\
\hline Lysine* & 75 & 42 & 50 & 35 \\
\hline Met + cystine* & 39 & 34 & 34 & 31 \\
\hline Phen + tyrosine* & 79 & 78 & 80 & 38 \\
\hline Valine* & 54 & 50 & 53 & 26 \\
\hline Total fat (g) & 65 & 38 & 43 & 44 \\
\hline Cholesterol (mg) & 302 & 0 & 10.8 & $<250$ \\
\hline Carbohydrates (g) & 242 & 392 & 375 & 325 \\
\hline Fiber $(g)$ & 18 & 54 & 42 & $30-55$ \\
\hline Vitamin C (mg) & 94 & 164 & 211 & $45-2000$ \\
\hline Folic acid $(\mu \mathrm{g})$ & 197 & 751 & 652 & $400-1000$ \\
\hline Vitamin $B_{1}(\mathrm{mg})$ & 1.94 & 3.52 & 3.2 & $1.2-\mathrm{NA}^{* *}$ \\
\hline Vitamin $B_{2}(\mathrm{mg})$ & 2.08 & 1.30 & 1.1 & $1.3-\mathrm{NA}^{* *}$ \\
\hline Vitamin $\mathrm{B}_{6}(\mathrm{mg})$ & 3.8 & 5.55 & 5.2 & $1.4-\mathrm{NA}^{* *}$ \\
\hline Niacin (mg) & 25 & 25 & 24 & 16-35 \\
\hline Vitamin $\mathrm{B}_{12}(\mu \mathrm{g})$ & 3.32 & 0.45 & 1.2 & 2.0-NA** \\
\hline Vitamin E (mg) & 10 & 10.0 & 11.9 & 9-1000 \\
\hline Vitamin A $(\mu \mathrm{g})$ & 2329 & 3266 & 2020 & $550-3000^{* * *}$ \\
\hline Potassium (mg) & 3832 & 3646 & 4400 & 2000-3500 \\
\hline Manganese (mg) & 2.19 & 16.0 & 14.0 & 2-11 \\
\hline Iron $(\mathrm{mg})$ & 11 & 24.0 & 20.7 & $18-53$ \\
\hline Calcium (mg) & 760 & 982 & 952 & $750-2500$ \\
\hline Phosphorus (mg) & 1494 & 1632 & 1804 & $800-4000$ \\
\hline Zinc (mg) & 10 & 15.4 & 14.3 & $12-40$ \\
\hline Magnesium (mg) & 325 & 754 & 720 & $250-350 * * * *$ \\
\hline Sodium (mg) & 3025 & 1724 & 2052 & $500-2300$ \\
\hline
\end{tabular}

${ }^{*} \mathrm{mg}$ of amino acid per gram of protein, ${ }^{* *}$ data not available, ${ }^{* * *}$ preformed vitamin A only, ${ }^{* * * *}$ tablets only.

3.25 , and $3.39 \mathrm{mmol} / \mathrm{L}$, at onset, 21 days and 3 months, respectively. Other biochemical indicators also showed a significant favorable tendency at $21 \mathrm{~d}$ and 3 months: urea dropped by $32.8 \%$ and $21 \%$, and the liver enzyme ALAT $18.8 \%$ and $19.5 \%$, respectively (Table 3 ).

Hemoglobin values showed a significant decrease; however, the reduction took place at expense of individual high values at onset, it can be deduced from the interval values (Table 3).

The values of the hemoglobin, total protein, and albumin indicate that the diet can be classified as nutritionally safe, at least during the evaluated time (Table 3).

Blood pressure decreased also significantly in a rapid way since the first 21 days (Table 2).

3.4. Consumption of Medications. After 21 days, the mean insulin consumption dropped by $46 \%$ (617 units); 3 months later up to 858 units $(64 \%)$ in relation to onset. The consumption of hypoglycemic pills did not show changes during the first 21 days, while 3 months later it had diminished in 10 pills (17\%).

\section{Discussion}

The fundamental therapy goals for diabetes mellitus [19] addressed to maintain low or as closer to normal as possible the values of glycemia, blood pressure, and serum lipoprotein levels, able to reduce the cardiovascular disease risk were accomplished by the results of this study. Nutritional interventions in diabetes have evidenced the capacity of diet to reduce the cardiovascular risk improving the metabolic control but only with discrete impact on drug consumption [20-23]. A recent assay in New Zealand diabetic adults [24], which reduced saturated fat and increased protein intake 
TABLE 2: Changes of anthropometric variables and arterial blood pressure during 3-month intervention with Ma-Pi 2 macrobiotic diet in type 2 diabetic adults.

\begin{tabular}{|c|c|c|c|c|c|c|}
\hline Variable & $\begin{array}{l}\text { Before } \\
n=61 \\
\end{array}$ & $\begin{array}{c}\text { After } 21 \mathrm{~d} \\
n=61\end{array}$ & $\begin{array}{c}\text { After } 3 \mathrm{~m} \\
n=54\end{array}$ & $\begin{array}{c}\text { Change } \\
\text { After } 21 \mathrm{~d}(\%)\end{array}$ & $\begin{array}{c}\text { Change } \\
\text { After } 3 \mathrm{~m}(\%)\end{array}$ & $P$ value \\
\hline Weight (kg) & $\begin{array}{c}76.2(17.8) \\
(47.4-133.0)\end{array}$ & $\begin{array}{c}73.5(17.0) \\
(44.0-128.0)\end{array}$ & $\begin{array}{c}72.5(16.7) \\
(42.0-121.4)\end{array}$ & -4 & -5 & 0.4992 \\
\hline $\operatorname{BMI}\left(\mathrm{kg} / \mathrm{m}^{2}\right)$ & $\begin{array}{c}28.8(5.4) \\
(21.6-48.3)\end{array}$ & $\begin{array}{c}27.7(5.1) \\
(20.1-46.5)\end{array}$ & $\begin{array}{c}27.4(5.1) \\
(19.2-44.1)\end{array}$ & -4 & -5 & 0.3355 \\
\hline Waist circumference $(\mathrm{cm})$ & $\begin{array}{c}95.8(11.6) \\
(71.0-126.0)\end{array}$ & $\begin{array}{c}93.0(11.4) \\
(65.0-122.0)\end{array}$ & $\begin{array}{c}91.6(11.3) \\
(64.0-120.0)\end{array}$ & -3 & -4 & 0.1278 \\
\hline Hip circumference $(\mathrm{cm})$ & $\begin{array}{l}103.5(11.3) \\
(86.0-136.0)\end{array}$ & $\begin{array}{l}101.4(10.9) \\
(84.0-134.0)\end{array}$ & $\begin{array}{c}99.7(10.5) \\
(84.0-134.0)\end{array}$ & -2 & -4 & 0.1781 \\
\hline Body fat (\%) & $\begin{array}{c}36.4(7.0) \\
(23.9-52.9)\end{array}$ & $\begin{array}{c}34.3(7.0) \\
(21.4-51.7)\end{array}$ & $\begin{array}{c}33.3(7.5) \\
(20.5-48.2)\end{array}$ & -6 & -9 & 0.0593 \\
\hline Lean body Mass (kg) & $\begin{array}{l}45.7(11.2) \\
(30.5-74.0)\end{array}$ & $\begin{array}{l}\mathbf{4 5 . 6}(10.8) \\
(29.8-71.3)\end{array}$ & $\begin{array}{l}45.6(11.0) \\
(30.4-72.7)\end{array}$ & -0.2 & -0.2 & 0.9993 \\
\hline Systolic pressure (mmHg) & $\begin{array}{l}127(19) \\
(90-180)\end{array}$ & $\begin{array}{l}113(12) \\
(90-140)\end{array}$ & $\begin{array}{c}118(7) \\
(93-133)\end{array}$ & -11 & -7 & $3,888 e^{-7}$ \\
\hline $\begin{array}{l}\text { Diastolic pressure } \\
(\mathrm{mmHg})\end{array}$ & $\begin{array}{c}76(12) \\
(57-100)\end{array}$ & $\begin{array}{c}69(8) \\
(50-85)\end{array}$ & $\begin{array}{c}75(5) \\
(63-83) \\
\end{array}$ & -9 & -1 & $5,092 e^{-5}$ \\
\hline
\end{tabular}

Values are represented as means (standard deviations), and (minimum and maximal values) $P<0.05$ was considered significant.

TABLE 3: Changes of serum biochemical indicators during 3-month intervention with Ma-Pi 2 macrobiotic diet in type 2 diabetic adults.

\begin{tabular}{|c|c|c|c|c|c|c|}
\hline Variable & $\begin{array}{l}\text { Before } \\
n=61\end{array}$ & $\begin{array}{c}\text { After } 21 \mathrm{~d} \\
n=61\end{array}$ & $\begin{array}{c}\text { After } 3 \mathrm{~m} \\
n=54\end{array}$ & $\begin{array}{c}\text { Change after } 21 \mathrm{~d} \\
(\%)\end{array}$ & $\begin{array}{c}\text { Change after } 3 \mathrm{~m} \\
(\%)\end{array}$ & $P$ value \\
\hline Glucose $(\mathrm{mmol} / \mathrm{L})$ & $\begin{array}{l}8.35(3.3) \\
(3.1-17.0)\end{array}$ & $\begin{array}{l}6.44(1.7) \\
(3.1-9.9)\end{array}$ & $\begin{array}{c}\mathbf{5 . 6 7}(1.9) \\
(2.64-10.2)\end{array}$ & -23 & -32 & $3.533 e^{-8}$ \\
\hline $\begin{array}{l}\text { Total cholesterol } \\
(\mathrm{mmol} / \mathrm{L})\end{array}$ & $\begin{array}{c}6.2(1.3) \\
(3.76-9.66)\end{array}$ & $\begin{array}{l}4.3(0.8) \\
(3.0-5.7)\end{array}$ & $\begin{array}{l}4.4(0.9) \\
(2.6-6.3)\end{array}$ & -31 & -29 & $2.2 e^{-16}$ \\
\hline $\begin{array}{l}\text { HDL cholesterol } \\
(\mathrm{mmol} / \mathrm{L})\end{array}$ & $\begin{array}{c}1.05(0.4) \\
(0.4-2.1)\end{array}$ & $\begin{array}{c}1.04(0.3) \\
(0.6-1.8)\end{array}$ & $\begin{array}{l}1.02(0.2) \\
(0.7-1.5)\end{array}$ & -5 & -3 & 0.8889 \\
\hline $\begin{array}{l}\text { LDL cholesterol } \\
(\mathrm{mmol} / \mathrm{L})\end{array}$ & $\begin{array}{l}3.86(1.2) \\
(1.2-6.3)\end{array}$ & $\begin{array}{l}2.51(0.9) \\
(0.2-5.5)\end{array}$ & $\begin{array}{c}2.65(1.0) \\
(0.3-5.2)\end{array}$ & -35 & -31 & $1.511 e^{-11}$ \\
\hline Triglycerides (mmol/L) & $\begin{array}{l}2.7(1.4) \\
(0.7-7.8)\end{array}$ & $\begin{array}{l}1.4(0.6) \\
(0.5-3.1)\end{array}$ & $\begin{array}{l}1.7(0.8) \\
(0.6-4.2)\end{array}$ & -48 & -37 & $1.384 e^{-11}$ \\
\hline Creatinine $(\mathrm{mmol} / \mathrm{L})$ & $\begin{array}{c}\mathbf{6 4 . 1}(17.3) \\
(33.0-117.0)\end{array}$ & $\begin{array}{c}61.2(14.3) \\
(38.0-106.0)\end{array}$ & $\begin{array}{l}\mathbf{5 7 . 7}(13.6) \\
(24.0-90.0)\end{array}$ & -4 & -10 & 0.0837 \\
\hline Urea (mmol/L) & $\begin{array}{c}5.7(1.5) \\
(2.6-10.7)\end{array}$ & $\begin{array}{l}3.8(1.0) \\
(2.0-6.8)\end{array}$ & $\begin{array}{l}4.5(1.0) \\
(2.0-6.7)\end{array}$ & -33 & -21 & $1.99 e^{-14}$ \\
\hline ALAT (units) & $\begin{array}{l}20.3(8.7) \\
(8.8-47.4)\end{array}$ & $\begin{array}{l}16.5(5.6) \\
(7.7-29.6)\end{array}$ & $\begin{array}{l}16.4(5.8) \\
(7.3-30.0)\end{array}$ & -19 & -19 & 0.0015 \\
\hline Leukocytes $\left(\times 10^{3} / \mathrm{L}\right)$ & $\begin{array}{c}\mathbf{8 . 0}(2.1) \\
(4.0-13.1)\end{array}$ & $\begin{array}{l}7.1(1.8) \\
(3.6-11.8)\end{array}$ & $\begin{array}{c}6.8(1.6) \\
(3.2-11.6)\end{array}$ & -11 & -15 & 0.0008 \\
\hline Hemoglobin (g/dL) & $\begin{array}{c}14.1(1.5) \\
(10.0-18.0)\end{array}$ & $\begin{array}{c}13.4(1.3) \\
(10.2-16.7)\end{array}$ & $\begin{array}{l}13.3(1.2) \\
(10.4-15.7)\end{array}$ & -5 & -6 & 0.0027 \\
\hline Total proteins $(\mathrm{g} / \mathrm{L})$ & $\begin{array}{c}76.3(9.1) \\
(35.9-90.8)\end{array}$ & $\begin{array}{c}74.1(8.1) \\
(36.5-86.4)\end{array}$ & $\begin{array}{c}76.0(4.9) \\
(65.1-85.8)\end{array}$ & -3 & -0.4 & 0.2416 \\
\hline Albumin (g/L) & $\begin{array}{c}34.3(4.6) \\
(13.1-41.9)\end{array}$ & $\begin{array}{c}36.0(4.6) \\
(14.2-45.6)\end{array}$ & $\begin{array}{c}35.5(5.3) \\
(26.2-46.9)\end{array}$ & 5 & 3 & 0.1325 \\
\hline
\end{tabular}

Values are represented as means (standard deviations), and (minimum and maximal values) $P<0.05$ was considered significant.

showed only a modest decrease of HbAlc (6\%), BMI (2\%), and waist circumference $(2 \%)$, and medication level, without changes in glycemia, serum lipids, and blood pressure, after six months of intervention. The saturated fat intake reduction improves insulin sensitivity, independently of the energy intake [25-27]; however, a sustained high protein intake is associated with increased incidence of type 2 diabetes and diabetic nephropathy [28]. High protein intakes can increase the insulin secretion non mediated by high blood glucose concentrations [29]. A 14-year followup study in 75,512 
TABLE 4: Glycemic profile evolution during 3-month intervention with Ma-Pi 2 diet in type 2 diabetic adults.

\begin{tabular}{|c|c|c|c|c|c|c|}
\hline Variable & $\begin{array}{l}\text { Time } 0 \\
n=61\end{array}$ & $\begin{array}{l}21 \text { days } \\
n=61\end{array}$ & $\begin{array}{c}3 \text { months } \\
n=54\end{array}$ & $\begin{array}{c}\text { Change } \\
\text { After } 21 \mathrm{~d} \\
(\%)\end{array}$ & $\begin{array}{c}\text { Change after } 3 \mathrm{~m} \\
(\%)\end{array}$ & $P$ value \\
\hline Fasting glucose $(\mathrm{mmol} / \mathrm{L})$ & $\begin{array}{c}9.2(3.1) \\
(3.30-17.7)\end{array}$ & $\begin{array}{l}5.7(1.4) \\
(3.0-8.7)\end{array}$ & $\begin{array}{c}\mathbf{6 . 6}(1.9) \\
(3.7-11.2)\end{array}$ & -38 & -28 & $8.554 \cdot e^{-15}$ \\
\hline $\begin{array}{l}\text { Glucose: } 2 \text { hours after } \\
\text { breakfast }(\mathrm{mmol} / \mathrm{L})\end{array}$ & $\begin{array}{l}12.1(4.6) \\
(4.2-22.1)\end{array}$ & $\begin{array}{l}6.8(1.91) \\
(2.9-11.0)\end{array}$ & $\begin{array}{l}7.7(2.17) \\
(3.7-12.4)\end{array}$ & -44 & -36 & $2.200 \cdot e^{-16}$ \\
\hline $\begin{array}{l}\text { Glucose: } 2 \text { hours after } \\
\text { lunch (mmol/L) }\end{array}$ & $\begin{array}{l}11.1(5.22) \\
(3.8-29.9)\end{array}$ & $\begin{array}{c}6.3(2.3) \\
(2.1-11.9) \\
\end{array}$ & $\begin{array}{c}7.7(2.7) \\
(3.6-12.0) \\
\end{array}$ & -44 & -31 & $2.581 \cdot e^{-11}$ \\
\hline
\end{tabular}

Values are represented as means (standard deviations), and (minimum and maximal values) $P<0.05$ was considered significant.

TABLE 5: Lipids and cardiovascular risk in adult type 2 diabetic adults with Ma-Pi 2 diet.

\begin{tabular}{|c|c|c|c|c|}
\hline Variable & Cut-off points & $\begin{array}{c}\text { Time } 0 \\
(\%)\end{array}$ & $\begin{array}{c}21 \text { days } \\
(\%)\end{array}$ & $\begin{array}{c}3 \text { months } \\
(\%)\end{array}$ \\
\hline \multirow{3}{*}{$\begin{array}{l}\text { Total cholesterol } \\
(\mathrm{mmol} / \mathrm{L})\end{array}$} & Desirable $<5.2$ & 28 & 87 & 74 \\
\hline & Borderline 5.2-6.19 & 21 & 11 & 24 \\
\hline & High risk $\geq 6.20$ & 51 & 2 & 2 \\
\hline \multirow{3}{*}{ LDL cholesterol (mmol/L) } & Desirable $<3.39$ & 30 & 87 & 76 \\
\hline & Borderline $3.38-4.10$ & 38 & 11 & 17 \\
\hline & High risk $\geq 4.11$ & 32 & 3 & 7 \\
\hline \multirow{3}{*}{$\begin{array}{l}\text { HDL cholesterol } \\
(\mathrm{mmol} / \mathrm{L})\end{array}$} & Desirable $>1.6$ & 4 & 2 & 0 \\
\hline & Acceptable 1.0-1.6 & 53 & 55 & 63 \\
\hline & High risk $\leq 1.0$ & 43 & 43 & 37 \\
\hline \multirow{4}{*}{ Triglycerides (mmol/L) } & Desirable $<1.7$ & 33 & 82 & 78 \\
\hline & Borderline $1.7-2.3$ & 35 & 18 & 20 \\
\hline & High 2.31-5.64 & 28 & 0 & 2 \\
\hline & High risk $\geq 5.65$ & 4 & 0 & 0 \\
\hline
\end{tabular}

Percentages of patients included in each classification according to measured serum values at onset, and after $21 \mathrm{~d}$ or 3 months of intervention.

Hawaiian adults recently evidenced, once more, the strongly positive association of red meat intake with diabetes risk [30]. Increased plasma amino acids concentration induces directly insulin resistance in skeletal muscles and stimulates the endogenous glucose production [31].

The higher energy intake observed during this intervention, in comparison to previous values, would indicate that other dietary factors as energy alone should be related to the results. This Cuban study shows a diet low in fat (only $16-18 \%$ of the daily energy), low in proteins (12\%), and high in whole grain cereals carbohydrates (70-72\%) acting alone as powerful medication. The high fiber, $\mathrm{Mn}, \mathrm{Mg}$, and $\mathrm{Zn}$ intake and the reduced fat and protein content of the diet $[2,3,7]$ have contributed to the observed decrease of the insulin demand. Only after 21 days, patients were able to control glycemia, serum lipids levels, and blood pressure. The fact that patients diminished further the insulin doses at 3 months indicates that they continued carrying out well enough their diet at home in spite of slightly dietary transgressions.

Whole grain cereals dietary fiber has been associated with better peripheral insulin sensibility and also with a higher pancreas betacells secretion [32]. An intake of $50 \mathrm{~g} /$ day (as recorded in this study) reduces glycemia, hyperinsulinemia, hyperlipemia, and cardiovascular risk in type 2 diabetes mellitus patients [33-36]. The mean whole rice intake of the patients was $300 \mathrm{~g}$ a day. Whole grain rice, besides its rich content in fiber, $\mathrm{Mg}$ and $\mathrm{Mn}$, contains 16 phyto compounds with recognized biological activity and a considerable quantity of fat soluble antioxidants like phytosterols, tocopherols and tocotrienols [37], linoleic acid (approx. 40\%), oleic acid (40\%), and alpha-linolenic acid, 1-3\%, quantity and composition enough for guaranteeing the required $n-3$ family polyunsaturated fatty acids supply. Tocotrienol inhibits the HMG-CoA reductase, key enzyme of the cholesterol synthesis, which awarded its potent hypolipidemic effect, besides its anticancerous and neuroprotective properties [38].

Discrete and nonsignificant body weight (5\%) and body fat $(4 \%)$ reductions were observed, parallel to the preservation of the lean body mass. In overweight and obese subjects with insulin resistance or type 2 diabetes, only a discrete body weight reduction improves insulin resistance, glycemia, and blood pressure [23, 39].

Hyperglycemia, hyperinsulinemia, hypertriglyceridemia, and high serum-free fatty acid levels are all characteristics of the prolonged diabetes mellitus. The maintenance of serum lipids in a normal range leads to reduced vascular 
TABLE 6: Serum lipid ratios related with cardiovascular risk in adult type 2 diabetic adults with Ma-Pi 2 diet.

\begin{tabular}{lccc}
\hline Ratio & Before & After 21d & After 3 m \\
\hline Total cholesterol/HDL cholesterol & 5.87 & 4.12 & 4.32 \\
LDL cholesterol/HDL cholesterol & 3.68 & 2.41 & 2.60 \\
Not HDL cholesterol/HDL cholesterol & 4.87 & 3.12 & 3.32 \\
\hline
\end{tabular}

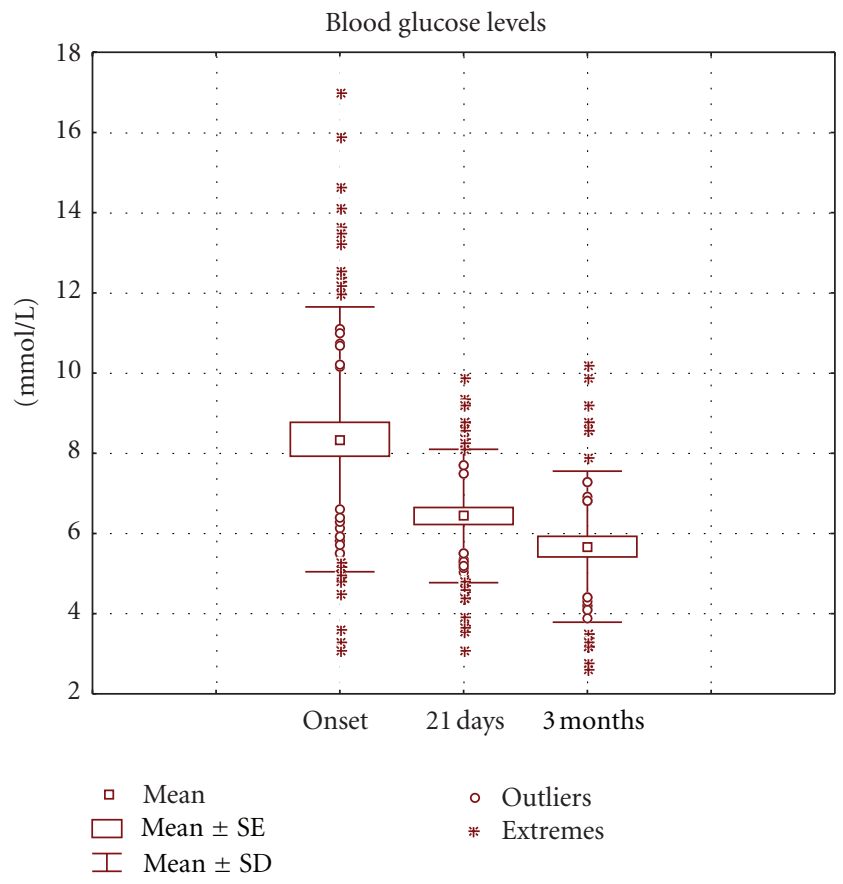

Figure 1: Evolution of the serum glucose levels of type 2 diabetic adults with Ma-Pi 2 diet. Note: the figure shows the mean values (squares), individual distant values (circles), and individual extreme values (asterisks) at 3 times of the assay: at onset, 21 days and 3 months after intervention with the assayed diet. The mustaches represent the standard deviation and the biggest squares the standard error of the mean. Values are expressed in $\mathrm{mmol} / \mathrm{L}$.

complications [40] mediated by endothelial dysfunction [41]. Serum lipids and cardiovascular risk decreased significantly in this intervention.

The hypertension levels do have predictive value in the progression prognosis of the diabetic micro- and macrovascular complications [42]. In this study, the blood pressure control was already reached after 21 days of intervention.

Bancha tea was the main source of liquids of the MaPi diet. Green (Bancha) tea polyphenols (epigallocateqchn gallate) increase 15 times the insulin activity in vitro, protect against oxidative damage [43], and inhibit the LDL cholesterol oxidation, associated with atherosclerosis risk, heart disease, and also with the formation of reactive oxygen specimens and free radicals [44].

The polyphenols content of the Ma-Pi 2 diet is $2664 \mathrm{mg}$ of gallic acid and the main contributors to this value are cereals $43 \%$, vegetables $30 \%$, leguminous $11 \%$, and sesame seeds $8 \%$ [45] versus $1171 \mathrm{mg}$ gallic acid in the Mediterranean Spanish diet, where drinks are main contributors, 50\% [46].

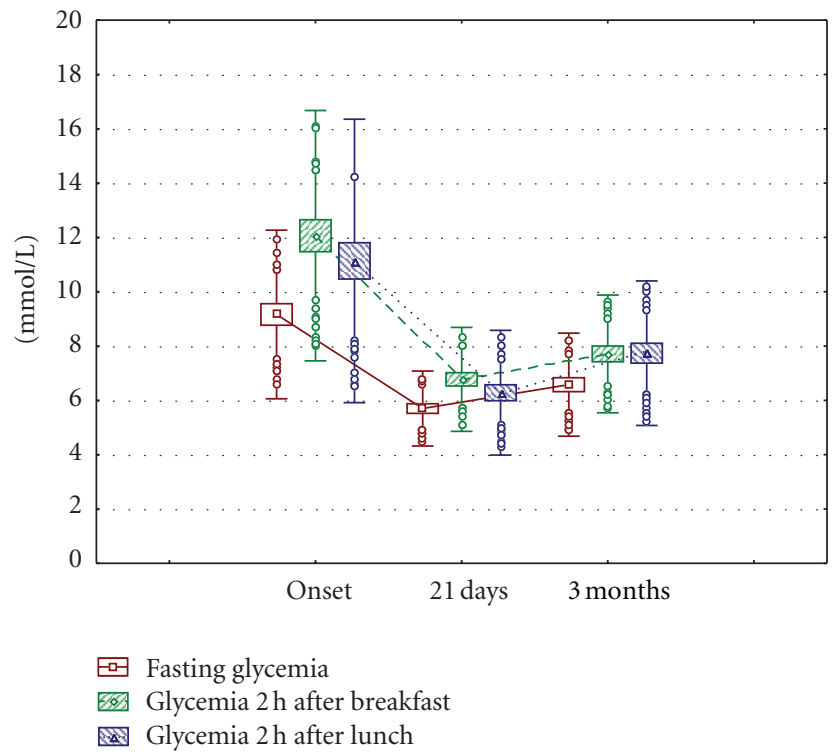

FIGURE 2: Glycemic profile evolution in type 2 diabetic adults with Ma-Pi 2 diet. Note: the figure shows the mean values (squares), individual distant values (circles), and individual extreme values (asterisks) at 3 times of the assay: at onset, 21 days and 3 months after intervention with the assayed diet. Mustaches represent the variation of the standard deviation and the biggest squares the variation of the standard error of the mean. Values are expressed in $\mathrm{mmol} / \mathrm{L}$.

The total antioxidant capacity of the Ma-Pi 2 diet, measured by the ABTS and FRAP methods in a parallel study, showed high values (8378 and $1571 \mathrm{mg}$ ascorbic acid, resp.) where main contributing foodstuffs to this records are vegetables, $36 \%$, and Bancha tea, $31 \%$ [45]. This value is much higher than the one reported for the Spanish Mediterranean Diet (1046 and $370 \mathrm{mg}$ ascorbic acid, resp.), where drinks (wine, coffee, and tea) are the main contributors with $65 \%$ [46].

The possible vitamin $B_{12}$ deficiency is an important side effect of the macrobiotic Ma-Pi 2 therapy to be considered. However, in previous Cuban studies, the serum vitamin $B_{12}$ level was not affected after 6 months with this diet [2]. Although this vitamin is highly storage and reutilized, caution should be recommended for prolonged therapy. The $6 \%$ drop of the previous hemoglobin high values after 6month should not have clinical translation. In a previous 6 months study in Cuban patients, anemia, microcitosis, or anisocitosis were not diagnosed and zinc protoporfirine $(\geq 80 \mu \mathrm{mol} / \mathrm{mol} \mathrm{hem})$ showed at assay end a low percentage of iron deficiency (4\% versus initial 6\%) [47]. Foods can no longer be evaluated only in terms of macronutrients and 


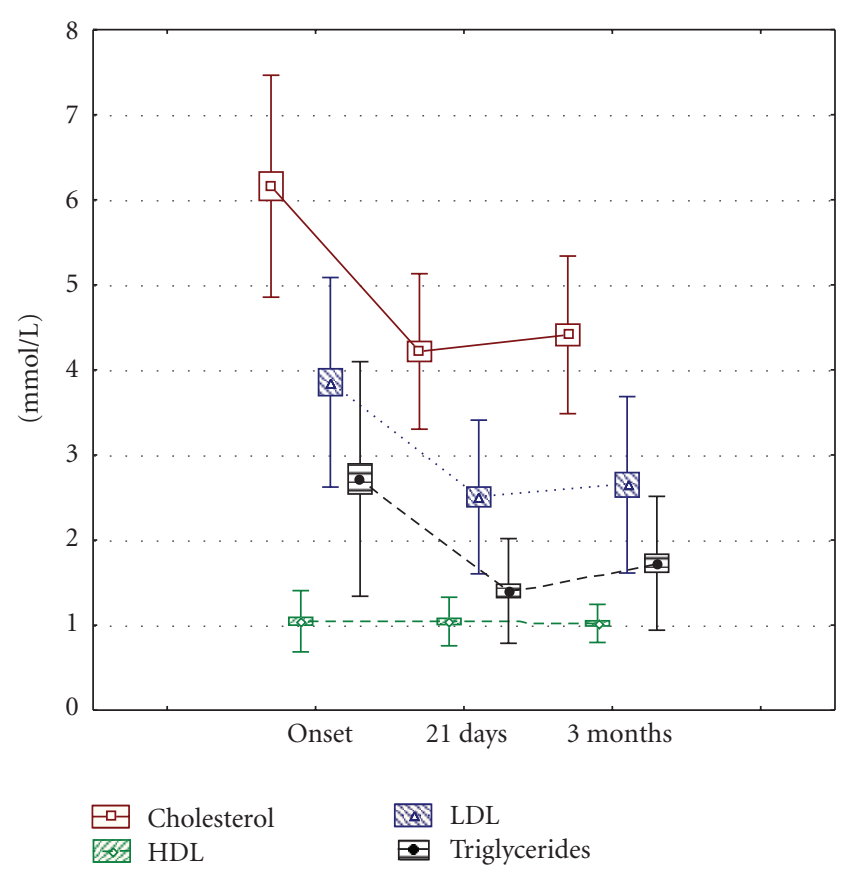

FIgUre 3: Evolution of the serum lipid indicators in type 2 diabetic adults with Ma-Pi 2 diet. Note: the squares represent the standard error of the mean and the mustaches the standard deviation. Values are expressed in $\mathrm{mmol} / \mathrm{L}$.

micronutrients content. Analyzing the content of other physiologically active components and evaluating their role in health promotion and therapeutic impact will be necessary, as it possibly happened in this intervention.

The high frequency of medical controls on these results could have an influence on the observed results; however, more attention should be perhaps addressed to the quality of nutritional advices than to the frequency of those controls. Patients included in this study were also regularly assisted at the DCC, before this intervention, for the lack of the diabetic metabolic control.

\section{Conclusions}

The potentiality of the Ma-Pi macrobiotic diet as therapeutic instrument for the rapid metabolic control of type 2 diabetic patients is supported by the positive effects observed at short term (21 days) on the glucose and lipid metabolism, blood pressure, body composition, and insulin consumption. The results reached at 3 months of dietary treatment, when the patient was the responsible for his own feeding, indicate the feasibility and adequacy of the offered instruction, which allowed diabetics to incorporate the learned principles to their daily feeding. The feasibility of this diet at the long term shall be assessed, especially when patients are not permanently under regular medical control. The performance of a clinical assay with a control group receiving the conventional recommended diet, which generated the metabolic results observed in these diabetic patients before intervention, is being evaluated from ethical points of view.

\section{Authors' Contribution}

C. Porrata-Maury helped in concepts, design, definition of intellectual content, literature search, clinical studies, experimental studies, data, acquisition, data analysis, statistical analysis, paper preparation, paper editing, and paper review. M. Hernández-Triana helped in definition of intellectual content, literature search, experimental studies, data, acquisition, data analysis, paper preparation, paper editing, and paper review. E. Rodríguez-Sotero helped in design, clinical studies, experimental studies, data, and acquisition. R. V. Dacosta-Calheiros helped in concepts, design, definition of intellectual content, literature search, clinical studies, experimental studies, data, acquisition, data analysis, statistical analysis, paper preparation, paper editing, and paper review. H. Hernández-Hernández helped in literature search, experimental studies, data, acquisition, data analysis, statistical analysis, paper preparation, paper editing, and paper review. M. Mirabal-Sosa helped in concepts, design, definition of intellectual content, literature search, clinical studies, experimental studies, data, acquisition, data analysis, statistical analysis, paper preparation, paper editing, and paper review. C. Campa-Huergo helped in concepts, design, definition of intellectual content, literature search, clinical studies, experimental studies, data, acquisition, data analysis, statistical analysis, paper preparation, paper editing, and paper review. M. Pianesi helped in concepts, design, definition of intellectual content, literature search, clinical studies, experimental studies, data, acquisition, data analysis, statistical analysis, paper preparation, paper editing, and paper review.

\section{References}

[1] J. E. Shaw, R. A. Sicree, and P. Z. Zimmet, "Global estimates of the prevalence of diabetes for 2010 and 2030," Diabetes Research and Clinical Practice, vol. 87, no. 1, pp. 4-14, 2010.

[2] C. Porrata-Maury, A. Abuín-Landín, A. Morales et al., "Efecto terapéutico de la dieta macrobiótica Ma-Pi 2 en 25 adultos con diabetes mellitus tipo 2," Revista Cubana de Investigaciones Biomédicas, vol. 26, no. 2, 2007, http://scielo.sld.cu/scielo.php?script=sci_arttext\&pid=S086403002007000200001\&lng=es\&nrm=iso.

[3] C. Porrata, J. Sánchez, V. Correa et al., "Ma-Pi 2 Macrobiotic diet intervention in adults with type 2 diabetes mellitus," MEDICC Review, vol. 11, no. 4, pp. 29-35, 2009, http://www.medicc.org/mediccreview/articles/mr_119.pdf.

[4] World Medical Assembly, Declaration of Helsinki: Ethical Principles for Medical Research on Human Beings, General Assembly, Scotland, 52nd edition, 2000, http://www.upo.es/ general/investigar/otri/otri_docu/pn/Decl_Helsinki.pdf.

[5] Definition and Diagnosis of Diabetes Mellitus and Intermediate Hyperglycemia: Report of a WHO/IDF consultation, World Health Organization, Geneva, Switzerland, 2006, http://www .who.int/diabetes/publications/Definition\%20and\%20diagnosis\%20of\%20diabetes_new.pdf.

[6] M. Pianesi, Las 5 Dietas Ma-Pi, Ediz L, Chi, Macerata, Italy, 2007.

[7] C. Porrata, M. Hernández, A. Abuín, C. Campa, and M. Pianesi, "Caracterización y evaluación nutricional de las 
dietas macrobióticas Ma-Pi," Revista Cubana de Investigaciones Biomédicas, vol. 27, no. 3-4, pp. 1-36, 2008, http://scielo.sld.cu/scielo.php?script=sci_arttext\&pid=S086403002008000300001\&lng=es\&nrm=iso.

[8] US Department of Agriculture, Agricultural Research Service, National Nutrient Database for Standard Reference, USDA Nutrient Data Laboratory Home Page, Washington, DC, USA, 2004, http://www.ars.usda.gov/Services/docs.htm? docid $=5717$.

[9] K. Hagiwara, "Standard tables of food composition in Japan Fifth Revised Edition," Journal for the Integrated Study of Dietary Habits, vol. 12, no. 2, pp. 86-89, 2001.

[10] Banca Dati di Composizione Degli Alimenti per Studi Epidemiologici in Italia, Istituto Europeo di Oncologia, Milan, Italy, 1998, http://www.ieo.it/bda2008/homepage.

[11] Banca Dati Interativa di Composizione Degli Alimenti, Istituto Nazionale di Recerca per gli alimenti e la Nutrizione, Roma, Italy, 2000, http://www.inran.it.

[12] Vitamin and Mineral Requirements, WHO, Geneva, Switzerland, 2nd edition, 2004.

[13] Dietary Reference Intakes for Energy, Carbohydrate, Fiber, Fat, Fatty Acids, Cholesterol, Protein, and Amino Acids (Macronutrients). Report of the Panel on Macronutrients, Subcommittees on Upper Reference Levels of Nutrients and Interpretation and Uses of Dietary Reference Intakes, and the Standing Committee on the Scientific Evaluation of Dietary Reference Intakes. i.e. Nacional Academies Press, USA, 2005, http://www.nap.edu/catalog.php?record_id=1049025.

[14] M. Hernández-Triana, C. Porrata, S. Jiménez-Acosta et al., "Dietary reference intakes for the Cuban population, 2008," MEDICC Review, vol. 11, no. 4, pp. 9-16, 2009.

[15] G. Sarwar, "Analytical issues related to food composition and protein quality," in Protein and Amino Acid Requirements in Human Nutrition. Report of a Joint WHO/FAO/UNU Expert Consultation, WHO Technical Report Series 935, WHO, Geneva, Switzerland, 2007.

[16] T. G. Lohman, A. F. Roche, and R. Martorell, Anthropometric Standardization Reference Manual, Human Kinetics Books, Champaign, Ill, USA, 1988.

[17] A. Carl Burtis, R. Edward Ashwood, and E. David Bruns, Eds., Tietz Textbook of Clinical Chemistry and Molecular Diagnostics, Elsevier Saunders, St. Louis, Mo, USA, 4th edition, 2006.

[18] Third Report of the National Cholesterol Education Program Expert Panel on Detection, Evaluation, and Treatment of High Blood Cholesterol in Adults (Adult Treatment Panel III), National Institutes of Health, Bethesda, Md, USA, 2002.

[19] American Diabetes Association, "Nutrition recommendations and interventions for diabetes. A position statement of the American Diabetes Association," Diabetes Care, vol. 31, supplement 1, pp. S61-S78, 2008.

[20] T. L. Perry, J. I. Mann, N. J. Lewis-Barned, A. W. Duncan, M. A. Waldron, and C. Thompson, "Lifestyle intervention in people with insulin-dependent diabetes mellitus (IDDM)," European Journal of Clinical Nutrition, vol. 51, no. 11, pp. 757-763, 1997.

[21] A. M. Wolf, M. R. Conaway, J. Q. Crowther et al., "Translating lifestyle intervention to practice in obese patients with type 2 diabetes: improving Control with Activity and Nutrition (ICAN) study," Diabetes Care, vol. 27, no. 7, pp. 1570-1576, 2004.

[22] M. Espeland, X. Pi-Sunyer, G. Blackburn et al., "Reduction in weight and cardiovascular disease risk factors in individuals with type 2 diabetes one-year results of the look AHEAD trial," Diabetes Care, vol. 30, no. 6, pp. 1374-1383, 2007.
[23] S. L. Norris, X. Zhang, A. Avenell et al., "Long-term effectiveness of weight-loss interventions in adults with pre-diabetes: a review," American Journal of Preventive Medicine, vol. 28, no. 1, pp. 126-139, 2005.

[24] K. J. Coppell, M. Kataoka, S. M. Williams, A. W. Chisholm, S. M. Vorgers, and J. I. Mann, "Nutritional intervention in patients with type 2 diabetes who are hyperglycaemic despite optimised drug treatment-lifestyle Over and Above Drugs in Diabetes (LOADD) study: randomised controlled trial," BMJ, vol. 341, Article ID c3337, 2010.

[25] G. Riccardi, R. Giacco, and A. A. Rivellese, "Dietary fat, insulin sensitivity and the metabolic syndrome," Clinical Nutrition, vol. 23, no. 4, pp. 447-456, 2004.

[26] H. Petersson, U. Risérus, J. McMonagle et al., "Effects of dietary fat modification on oxidative stress and inflammatory markers in the LIPGENE study," British Journal of Nutrition, vol. 104, no. 9, pp. 1357-1362, 2010.

[27] M. Haag and N. G. Dippenaar, "Dietary fats, fatty acids and insulin resistance: short review of a multifaceted connection," Medical Science Monitor, vol. 11, no. 12, pp. RA359-RA367, 2005.

[28] A. E. Buyken, P. Mitchell, A. Ceriello, and J. Brand-Miller, "Optimal dietary approaches for prevention of type 2 diabetes: a life-course perspective," Diabetologia, vol. 53, no. 3, pp. 406$418,2010$.

[29] R. N. Larsen, N. J. Mann, E. Maclean, and J. E. Shaw, "The effect of high-protein, low-carbohydrate diets in the treatment of type 2 diabetes: a 12 month randomised controlled trial," Diabetologia, vol. 54, no. 4, pp. 731-740, 2011.

[30] A. Steinbrecher, E. Erber, A. Grandinetti, L. N. Kolonel, and G. Maskarinec, "Meat consumption and risk of type 2 diabetes: the Multiethnic Cohort," Public Health Nutrition, vol. 14, no. 4, pp. 568-574, 2011.

[31] M. Promintzer and M. Krebs, "Effects of dietary protein on glucose homeostasis," Current Opinion in Clinical Nutrition and Metabolic Care, vol. 9, no. 4, pp. 463-468, 2006.

[32] A. D. Liese, A. K. Roach, K. C. Sparks, L. Marquart, R. B. D'Agostino Jr., and E. J. Mayer-Davis, "Whole-grain intake and insulin sensitivity: the Insulin Resistance Atherosclerosis Study," American Journal of Clinical Nutrition, vol. 78, no. 5, pp. 965-971, 2003.

[33] V. Vuksan, A. L. Rogovik, E. Jovanovski, and A. L. Jenkins, "Fiber facts: benefits and recommendations for individuals with type 2 diabetes," Current Diabetes Reports, vol. 9, no. 5, pp. 405-411, 2009.

[34] M. J. Franz, M. A. Powers, C. Leontos et al., "The evidence for medical nutrition therapy for type 1 and type 2 diabetes in adults," Journal of the American Dietetic Association, vol. 110, no. 12, pp. 1852-1889, 2010.

[35] K. Pegklidou, I. Nicolaou, and V. J. Demopoulos, "Nutritional overview on the management of type 2 diabetes and the prevention of its complications," Current Diabetes Reviews, vol. 6, no. 6, pp. 400-409, 2010.

[36] W. J. Craig and A. R. Mangels, "Position of the American Dietetic Association: vegetarian diets," Journal of the American Dietetic Association, vol. 109, no. 7, pp. 1266-1282, 2009.

[37] M. Sugano and E. Tsuji, "Rice bran oil and cholesterol metabolism," Journal of Nutrition, vol. 127, no. 3, 1997.

[38] C. K. Sen, S. Khanna, and S. Roy, "Tocotrienols in health and disease: the other half of the natural vitamin E family," Molecular Aspects of Medicine, vol. 28, no. 5-6, pp. 692-728, 2007.

[39] S. Klein, N. F. Sheard, X. Pi-Sunyer et al., "Weight management through lifestyle modification for the prevention and 
management of type 2 diabetes: rationale and strategies-a statement of the American Diabetes Association, the North American Association for the Study of Obesity, and the American Society for Clinical Nutrition," Diabetes Care, vol. 27, no. 8, pp. 2067-2073, 2004.

[40] L. J. Appel, M. W. Brands, S. R. Daniels, N. Karanja, P. J. Elmer, and F. M. Sacks, "Dietary approaches to prevent and treat hypertension: a scientific statement from the American Heart Association," Hypertension, vol. 47, no. 2, pp. 296-308, 2006.

[41] J. S. Petrofsky, “The effect of type-2-diabetes-related vascular endothelial dysfunction on skin physiology and activities of daily living," Journal of Diabetes Science and Technology, vol. 5, no. 3, pp. 657-667, 2011.

[42] V. Savica, G. Bellinghieri, and J. D. Kopple, "The the effect of nutrition on blood pressure," Annual Review of Nutrition, vol. 30, pp. 365-401, 2010.

[43] K. Igarashi, K. Honma, O. Yoshinari, F. Nanjo, and Y. Hara, "Effects of dietary catechins on glucose tolerance, blood pressure and oxidative status in Goto-Kakizaki rats," Journal of Nutritional Science and Vitaminology, vol. 53, no. 6, pp. 496500, 2007.

[44] S. Gomikawa, Y. Ishikawa, W. Hayase et al., "Effect of ground green tea drinking for 2 weeks on the susceptibility of plasma and LDL to the oxidation ex vivo in healthy volunteers," Kobe Journal of Medical Sciences, vol. 54, no. 1, pp. E62-E72, 2008.

[45] D. González Montesino, Capacidad antioxidante y aporte de polifenoles de la dieta macrobiótica implementada en el Instituto Finlay [thesis], Opción al Título Académico de Master en Ciencias y Tecnología de los Alimentos. Facultad de Farmacia y Alimentos. Universidad de la Habana, Junio, Cuba, 2009.

[46] F. Saura-Calixto and I. Goñi, "Antioxidant capacity of the Spanish Mediterranean diet," Food Chemistry, vol. 94, no. 3, pp. 442-447, 2006.

[47] G. Pita, M. Hernández-Triana, C. Porrata, M. A. Sánchez, C. Arocha, and M. E. Díaz, "Evaluación de la anemia y deficiencia de hierro en pacientes con diabetes mellitus tipo 2 y dieta macrobiótica, Cuba," Revista Chilena de Nutrición, vol. 36, supplement 1, article 436. 


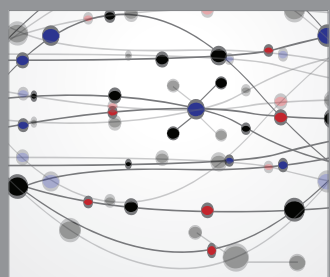

The Scientific World Journal
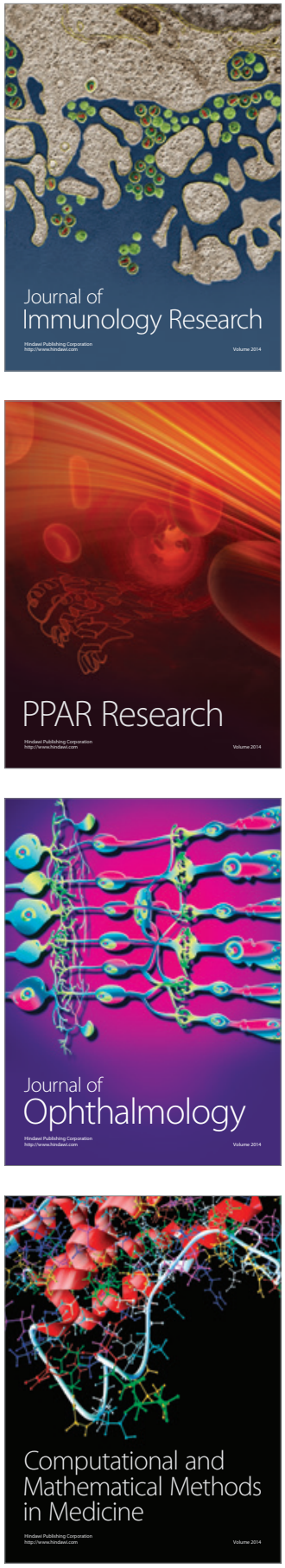

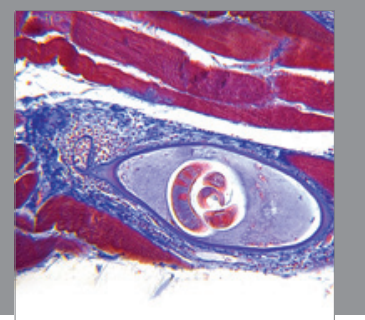

Gastroenterology

Research and Practice
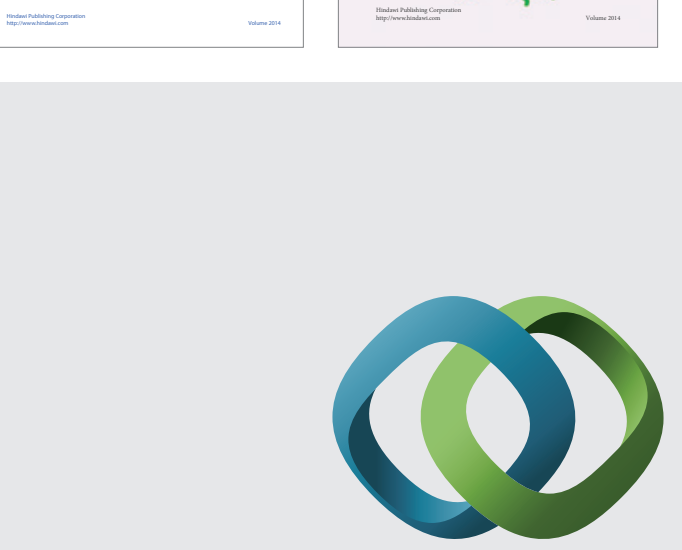

\section{Hindawi}

Submit your manuscripts at

http://www.hindawi.com
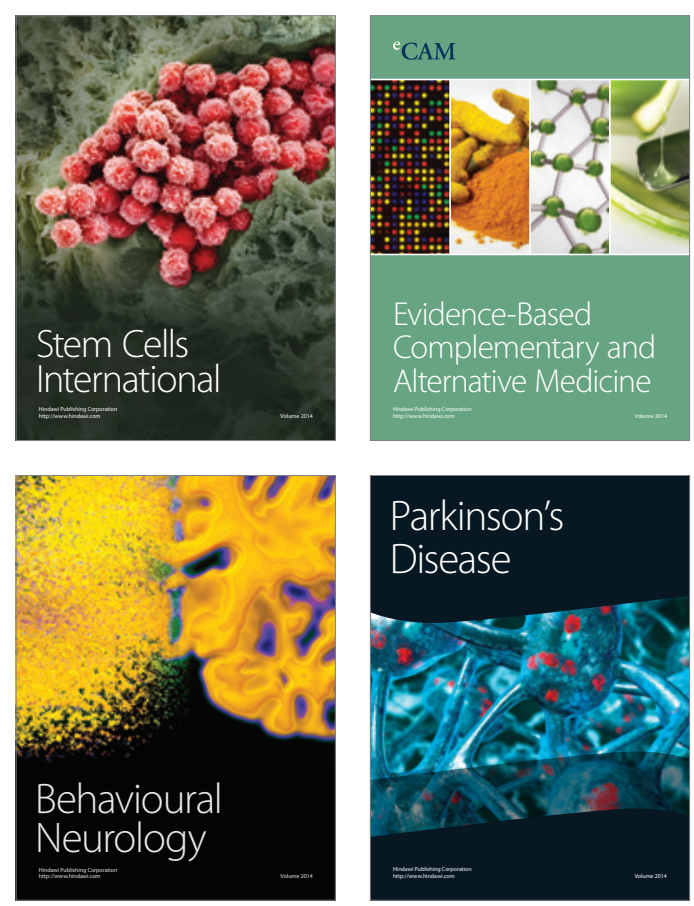

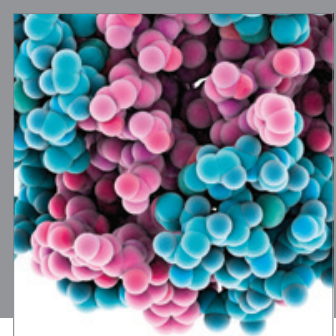

Journal of
Diabetes Research

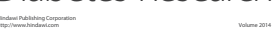

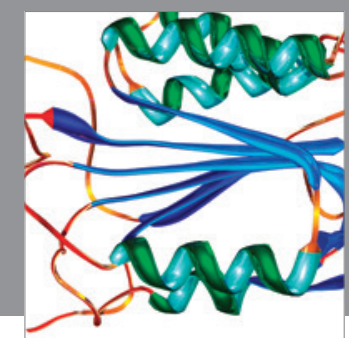

Disease Markers
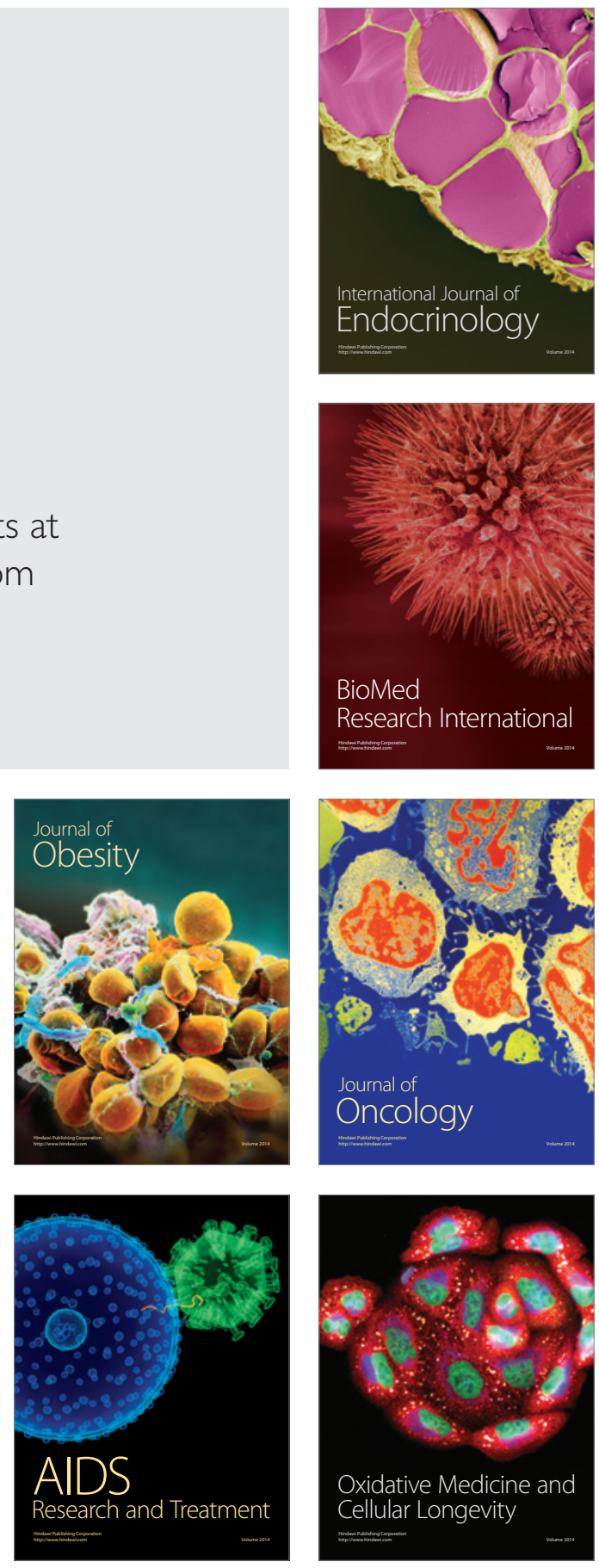